Spinning War and Peace:

Foreign Relations and Public Relations on the Eve of World War II

\author{
Andrew Johnstone \\ University of Leicester
}

\begin{abstract}
The eve of World War II saw the development of direct connections between public relations experts and issues of foreign affairs in the United States. Public relations professionals assisted both internationalists and non-interventionists to spread their arguments across the nation, helping them to hone their messages, to organize, and to raise money. All of the main citizens' organizations created during this period sought public relations assistance in the face of growing popular awareness of global events, and with an awareness of the need for public relations counsel in the face of an increasingly measurable concept of public opinion.
\end{abstract}




\title{
Spinning War and Peace:
}

\section{Foreign Relations and Public Relations on the Eve of World War II}

\author{
Andrew Johnstone \\ University of Leicester
}

In the words of industry pioneer Edward Bernays, public relations is "the attempt, by information, persuasion, and adjustment, to engineer public support for an activity, cause, movement, or institution.” It was therefore no surprise that a standard day for a public relations professional in 1940 included sending telegrams, attending meetings about organizational strategy and fundraising, making arrangements for radio broadcasts, or even arranging window displays for publicity purposes. Rarely ever did these professionals discuss State Department policy on arms sales, locate pictures of European refugees, promote the concept of conscription, or draft promotional material urging Americans to give maximum military aid to Britain. Yet these were all among the many tasks undertaken in 1940 by employees of the New York based John Price Jones Corporation. ${ }^{1}$

Of course, the situation in 1940 was not normal. The nation was in the middle of a great debate over its place in the world, a debate that saw hundreds of thousands of citizens join organizations that reflected their views. Most notable were the non-interventionist

\footnotetext{
* Andrew Johnstone is Associate Professor of American History at the University of Leicester. He is grateful to Brooke Blower, Heather Dichter, David Ekbladh, George Lewis, and to the anonymous reviewers for their helpful comments on earlier drafts.

${ }^{1}$ Edward L. Bernays, ed., The Engineering of Consent (Norman: University of Oklahoma Press, 1955), 3-4.
} 
America First Committee and, on the other side of the debate, the internationalist Committee to Defend America by Aiding the Allies. ${ }^{2}$ Yet these organizations, which helped shape the public debate over the war, were themselves defined in no small part by the work of public relations professionals. So pervasive was the growing faith in the power of public relations that both sides of the debate sought to harness that power. Indeed, all of the organizations created in response to the world crisis obtained public relations assistance to amplify their messages at a time of growing public concern regarding global events and a heightened awareness of both the concept and the power of public opinion. The eve of World War II saw

\footnotetext{
${ }^{2}$ On the non-interventionists, see Justus D. Doenecke, Storm on the Horizon (Lanham:
} Rowman and Littlefield, 2000); Wayne S. Cole, America First (Madison: University of Wisconsin Press, 1953). On the internationalists see Andrew Johnstone, Against Immediate Evil: American Internationalists and the Four Freedoms on the Eve of World War II (Ithaca: Cornell University Press, 2014); Donald J. Friedman, The Road From Isolation: The Campaign of the American Committee for Non-Participation in Japanese Aggression 19381941 (Cambridge: Harvard University Press, 1970); Walter Johnson, The Battle Against Isolation (Chicago: University of Chicago Press, 1944); Mark Lincoln Chadwin, The Hawks of World War II (Chapel Hill: University of North Carolina Press, 1968). On the broader concepts of “isolationism” and “internationalism” see Andrew Johnstone, "Isolationism and Internationalism in American Foreign Relations,” Journal of Transatlantic Studies, 9 (March 2011), 7-20; Brooke Blower, “From Isolationism to Neutrality: A New Framework for Understanding American Political Culture, 1919-1941,” Diplomatic History, 38 (April 2014), 345-376. 
the beginning of direct ties between public relations firms and foreign relations, ties which have had lasting significance. ${ }^{3}$

This article examines the connections between public relations and foreign affairs through three relationships between public relations firms and citizens' organizations on the eve of World War II. The John Price Jones Corporation worked closely with a number of internationalist organizations, most notably with the Committee to Defend America by Aiding the Allies; Tamblyn and Brown had a brief and less effective relationship with Fight for Freedom; and James Selvage of Selvage and Smith had a close yet informal relationship with the America First Committee. Those differing relationships reveal the largely unseen role of corporate actors in the arguments over America's role in the world between 1938 and 1941, as businessmen took sides in the great debate.

By 1941 public relations experts assisted both internationalists and noninterventionists in spreading their message across the nation. They did so in a number of ways that have gone unrecognized: providing foreign policy organizations with advice on publicity and fundraising, assisting them with organizational structures, and providing personnel to staff their offices. They helped foreign policy messages reach a wide national audience, but they also strongly promoted an approach that targeted specific and representative sections of society. The fact that foreign relations organizations found public

\footnotetext{
${ }^{3}$ The only brief previous acknowledgements of a public relations connection to these organizations are in John W. Masland, "Pressure Groups and American foreign policy,” Public Opinion Quarterly, 6 (Spring 1942), 119; Justus D. Doenecke, ed., In Danger Undaunted: The Anti-Interventionist Movement of 1940-1941 as Revealed in the Papers of the America First Committee (Stanford: Hoover Institution Press, 1990), 29; and Johnstone, Against Immediate Evil, 25, 60, 82-83, 111-12, 121.
} 
relations firms that matched their world views only strengthened the connections between them. The suggested public relations advice was often forceful as a result, especially on policy, and sometimes even stronger than the organizations desired. Given the heightened awareness of public opinion at the time, it is no surprise that the close relationship between foreign relations and public relations continued throughout the war and beyond. ${ }^{4}$

Yet despite Emily Rosenberg's call for greater consideration of public relations, mass consumerism and marketing, historians have barely considered the business of public relations in the United States with regard to foreign relations issues. ${ }^{5}$ In a broader sense, historians of public relations have focused primarily on the impact of public relations firms

\footnotetext{
${ }^{4}$ Other key studies on this period that consider public opinion but ignore public relations include David Kaiser, No End Save Victory: How FDR Led the Nation into War (New York: Basic Books, 2014); Susan Dunn, 1940: FDR, Willkie, Lindbergh, Hitler - the Election amid the Storm (New Haven: Yale University Press, 2013); Lynne Olsen, Those Angry Days: Roosevelt, Lindbergh, and America’s fight over World War II (New York: Random House, 2013); David Reynolds, From Munich to Pearl Harbor: Roosevelt's America and the Origins of the Second World War (Chicago: Ivan R. Dee, 2001); Waldo Heinrichs, Threshold of War: Franklin D. Roosevelt and American Entry into World War II (Oxford: Oxford University Press, 1988); William L. Langer and S. Everett Gleason, The Challenge to Isolation, 19371940 (New York: Harper, 1952); William L. Langer and S. Everett Gleason, The Undeclared War, 1940-1941 (New York: Harper, 1953).

${ }^{5}$ Emily S. Rosenberg, “U.S. Mass Consumerism in Transnational Perspective” in America in the World: The Historiography of American Foreign Relations since 1941, ed. Frank Costigliola and Michael J. Hogan (Cambridge: Cambridge University Press, 2014), 325.
} 
on the domestic corporate world. ${ }^{6}$ On the other hand, scholars of American foreign relations have considered public relations only very broadly, and almost wholly through considerations of propaganda and of governmental institutions. ${ }^{7}$ Nor has the recent boom in studies on

\footnotetext{
${ }^{6}$ On public relations, see Scott M. Cutlip, The Unseen Power: Public Relations. A History (Hillsdale: Lawrence Erlbaum, 1994); Richard S. Tedlow, Keeping the Corporate Image:
} Public Relations and Business, 1900-1950 (Greenwich: JAI Press, 1979); Stuart Ewen, PR! A Social History of Spin (New York: Basic Books, 1996). The annual International History of Public Relations Conference began in 2010, reflecting a growing interest in the history of the subject, an interest also seen in the publication of David Greenberg, Republic of Spin: An Inside History of the American Presidency (New York: W.W. Norton, 2016). On Bernays, see Larry Tye, The Father of Spin: Edward L. Bernays and the Birth of Public Relations (New York: Henry Holt, 1998). On fundraising, see Scott M. Cutlip, Fund Raising in the United States: Its Role in American Philanthropy (New Brunswick: Rutgers University Press, 1965); Oliver Zunz, Philanthropy in America: A History (Princeton: Princeton University Press, 2012).

${ }^{7}$ On domestic World War I propaganda, see Stephen Vaughn, Holding Fast the Inner Lines: Democracy, Nationalism, and the Committee on Public Information (Chapel Hill: University of North Carolina Press, 1980). For concerns about propaganda during the interwar years, see Brett Gary, The Nervous Liberals: Propaganda Anxieties from World War I to the Cold War (New York: Columbia University Press, 1999). For studies of the government's propaganda apparatus during World War II see Allan M. Winkler, The Politics of Propaganda: The Office of War Information 1942-1945 (New Haven: Yale University Press, 1978). 
public diplomacy seen direct connections drawn to public relations techniques. ${ }^{8}$ And despite a growing literature on the connections between the corporate world and politics, links between the history of foreign relations and business history have been largely overlooked, but those links are nevertheless important in understanding public support for foreign policy adventures. ${ }^{9}$

The new connection between public relations companies and foreign relations issues on the eve of World War II reflected a growing awareness in the United States of crises in Europe and Asia, but it meant more than that. It signaled an acknowledgment that this looming conflict was, in the words of the America First Committee’s R. Douglas Stuart, a "war of ideas". Those ideas about international affairs needed to be amplified, explained and reiterated to the nation. The connection between foreign relations and public relations also

${ }^{8}$ On public diplomacy, see Nicholas J. Cull, The Cold War and the United States Information Agency: American Propaganda and Public Diplomacy, 1945-1989 (Cambridge: Cambridge University Press, 2008); Laura A. Belmonte, Selling the American Way: U.S. Propaganda and the Cold War (Philadelphia: University of Pennsylvania Press, 2008); Justin Hart, Empire of Ideas: The Origins of Public Diplomacy and the Transformation of U.S. Foreign Policy, (Oxford: Oxford University Press, 2013). On the idea of World War II as a public relations war in a broader sense, see Paul Fussell, Wartime: Understanding and Behaviour in the Second World War (Oxford: Oxford University Press, 1989), 143-64.

${ }^{9}$ See for example, Wendy L. Wall, Inventing the 'American Way': The Politics of Consensus from the New Deal to the Civil Rights Movement (Oxford: Oxford University Press, 2008); Kim Phillips-Fein, Invisible Hands: The Businessman's Crusade Against the New Deal (New York: W. W. Norton, 2009); and Mark R. Wilson, Destructive Creation: American Business and the Winning of World War II (Philadelphia: University of Pennsylvania Press, 2016). 
highlighted a growing consensus about the importance of public opinion in an increasingly democratic and "mass" society, while revealing a desire to try and manage, persuade and alter that opinion if necessary. Politicians cautiously but quickly followed the citizens’ groups in recognizing the potential of this persuasive power in selling foreign policy positions. ${ }^{10}$

\section{Connecting Public Relations and Foreign Relations}

The debate over entry into World War II helped establish a lasting connection between public relations and foreign affairs. The public relations profession evolved rapidly through the early years of the twentieth century. As historian Richard Tedlow has argued, the profession of public relations in this period can be broadly defined as "controlling the news... by planned and organized effort through informing and cultivating the press and through encouraging the corporation itself to alter its policies in accord with perceived public desires.” Most importantly here, public relations experts worked closely with organizations to create policy. The profession therefore moved beyond the "press agentry" of the nineteenth century where externally hired publicists took orders from corporate management. It also offered a more subtle and sophisticated approach than simple advertising. ${ }^{11}$

\footnotetext{
${ }^{10}$ Stuart to Hanford MacNider, 30 Aug. 1941, Correspondence with Nat Com members folder, box 63, America First Committee Papers, Hoover Institution Archives (hereafter AFC Papers).

${ }^{11}$ Tedlow, Keeping the Corporate Image, xviii. For recent work that broadens the definition of public relations beyond corporate professionals, see Tom Watson, ed., North American Perspectives on the Development of Public Relations: Other Voices (London: Palgrave
} Macmillan, 2017). 
The first significant encounter between the burgeoning public relations concept and foreign relations came with the wartime success of George Creel's Committee on Public Information during World War I. As Scott Cutlip has argued, the wartime success of Creel's short-lived Committee on Public Information and the Liberty Loan drives "created a widespread awareness and blind faith in the power of publicity” at the end of World War I. Creel's success was reinforced by the public campaigns for prohibition and women's suffrage that culminated at the end of the war. As a result, the era saw the rapid expansion of public relations as an industry, as well as seeing numerous studies on the concept of public opinion, most notably Walter Lippmann’s Public Opinion in 1922, and Crystallizing Public Opinion by Edward Bernays the following year. ${ }^{12}$

Most public relations firms focused on domestic business accounts in the interwar years. Although exceptions arose in the 1930s, connections between public relations and foreign relations were strained as American politicians became increasingly wary of the work of public relations firms to promote foreign businesses and governments. The controversial nature of reports in 1934 linking American firms to Nazi Germany raised concerns with the US government about the relationship between public relations and foreign affairs, notably Ivy Lee’s counseling work for German chemical firm I. G. Farben, and the work of Carl Byoir and Associates with the German Railroads Tourist Bureau. Fears that both firms acted as propagandists for the Nazi regime brought them to the attention of the new Special Committee on Un-American Activities in the House of Representatives, which heightened concerns over the influence of foreign propaganda in the United States. Those suspicious

\footnotetext{
${ }^{12}$ Cutlip, Unseen Power, 105; Walter Lippmann, Public Opinion (New York: Macmillan, 1922); Edward L. Bernays, Crystallizing Public Opinion (New York: Boni and Liveright, 1923). On the Committee on Public Information, see Vaughn, Holding Fast the Inner Lines.
} 
international connections combined over the next four years with further investigations into (and fears of) un-American activity, growing regrets over the nation's entry into war in 1917, and developing concerns over international stability, creating an atmosphere of noninterventionism. Americans increasingly remembered the Committee on Public Information with suspicion as an agency that had misled them about the nature of World War I. This historical memory led to a strong popular desire to avoid further foreign entanglements. ${ }^{13}$

However, the growing crises in both Asia and Europe led a number of internationally minded American citizens to believe that an effort was required to persuade the rest of the country of the need to respond to overseas aggression. Troubled by the non-interventionist mood between 1938 and 1941, internationalists organized to alter that mood in the form of the American Committee for Non-participation in Japanese Aggression, the Committee to Defend America by Aiding the Allies, and Fight for Freedom. They sought to limit the trade between the United States and aggressors, revise the restrictive Neutrality Acts passed by Congress between 1935 and 1937, and ultimately provide greater aid to victims of international aggression. They aimed to direct popular opinion at the government, in the hope of proving to a cautiously internationalist Franklin Roosevelt that American opinion supported greater international action, and to prove to a strongly non-interventionist Congress that American opinion was sympathetic to victims of aggression.

Such efforts were necessary because both the Roosevelt administration and Congress were increasingly aware of public opinion, as represented through the new social science of opinion polling, which highlighted just how much Americans wanted to remain aloof from

\footnotetext{
${ }^{13}$ Cutlip, Unseen Power, 73-91, 140-153, 547-551; Tedlow, Keeping the Corporate Image, 91-92. On Ivy Lee, see Ray Eldon Hiebert, Courtier to the Crowd: the Story of Ivy Lee and the Development of Public Relations (Ames: Iowa State University Press, 1966).
} 
world affairs. Polling only heightened the existing sense that public opinion mattered. In 1935, George Gallup created the American Institute of Public Opinion at Princeton and Elmo Roper started polling for Fortune magazine. Hadley Cantril followed both into public opinion research, creating Princeton University's Office of Public Opinion Research in 1940. The political significance of a measurable public opinion had never been greater. ${ }^{14}$

With Roosevelt reluctant to create a national propaganda agency of any kind, the private internationalist movement led the way in terms of shaping public opinion. They organized and fought the public relations battle for opinion in a way the president could not, and in doing so they took full advantage of professional public relations assistance. The internationalists needed every possible tool to sway the strongly non-interventionist public, and the concept of public relations offered something new. Roosevelt was happy for the internationalists to lead the way, though he and the government then followed their lead once the United States joined the war. Of course, the great debate had two sides, and the noninterventionist forces felt compelled to respond. They too attempted to utilize public relations professionals to spread their message as widely and effectively as possible. The immediacy of the domestic debate over war allowed public relations professionals a route back into foreign policy considerations, moving beyond the idea that they simply offered propaganda for the U.S. government or for foreign nations. ${ }^{15}$

${ }^{14}$ On the growth of opinion polling, see Sarah E. Igo, The Averaged American: Surveys, Citizens and the Making of a Mass Public (Cambridge: Harvard University Press, 2007), 10349.

${ }^{15}$ On Roosevelt's awareness of the power of public opinion, see Steven Casey, Cautious Crusade: Franklin D. Roosevelt, American Public Opinion, and the War Against Nazi Germany (Oxford: Oxford University Press, 2001), 3-45. 


\section{Finding Fighting Objectives: Organized Internationalism}

The outbreak of war in Asia in 1937 and Europe in 1939 saw a considerable increase in advocacy for victims of international aggression. Americans became increasingly concerned with international events, and that concern led activists to create new organizations to promote aid to victims of aggression and greater engagement with world affairs. To help turn the tide of public opinion and heighten awareness of the developing conflict in Asia, the American Committee for Non-Participation in Japanese Aggression formed in 1938. The Non-Partisan Committee for Peace Through Revision of the Neutrality Law organized the following year after the outbreak of war in Europe. After the Nazi blitzkrieg in 1940, the most well-known citizens' organization of this period, the Committee to Defend America by Aiding the Allies, was established. All sought to sway American opinion, in terms of both mass popular opinion and governmental opinion, and they all recognized the need for public relations advocacy to strengthen their message in the face of a public wary of foreign entanglements. As a result, all three utilized the assistance of the John Price Jones Corporation, the public relations firm at the heart of internationalist efforts to resist fascist aggression. The fact the internationalists turned to a public relations company for assistance was a natural result of the previous two decades.

John Price Jones founded his eponymous Corporation in 1919. A former reporter and advertising executive, Jones made his name during World War I heading up publicity for the Liberty Loan campaigns that raised almost \$14 billion for the U.S. government, and he followed this with a similarly successful enormous fundraising campaign at his alma mater, Harvard. Building on his achievements, Jones incorporated his own firm "to give council and service in organization and publicity to business houses, institutions of public, semi-public, and private character, and to individuals.” Jones intended to build a business that dealt with 
both public relations and fundraising, and while the Corporation became best known as a fund raising organization rather than a public relations specialist it continued to work in both areas. $^{16}$

The Corporation's effectiveness was largely due to its systematic and standardized approach to its fundraising and public relations campaigns. While conceding that each individual campaign was different, the Corporation had a broadly standard procedure based on an eight point plan: from defining the campaign, to investigating, analyzing and planning for the campaign, to assisting with, overseeing, evaluating, and recording the success of the campaign. To support its campaigns, the Corporation relied on its own historic records, reference books and research, and most notably a classified list of some 38,500 individuals known to have donated over $\$ 850$ million to various causes (described boastfully by the Corporation as “perhaps the most comprehensive ‘who’s who in philanthropy’ existent”). In order to judge potential influence of individuals, the Corporation also boasted of a special file "showing not only the business associations of many prominent New Yorkers, but also their family relationships by blood and marriage.” This socially scientific approach to fundraising and public relations was perfectly suited to the post-World War I era where numerous public relations firms thrived. While the Corporation's claim to have been the "largest public

${ }^{16}$ Scott M. Cutlip et al., Effective Public Relations (Upper Saddle River: Prentice-Hall, 2000), 122; Cutlip, Unseen Power, 227-28; Cutlip, Fund Raising in the United States, 17274; Zunz, Philanthropy in America, 67; Jones cited in Cutlip, Unseen Power, 226; Cutlip, The Unseen Power, 107, 232-34. 
relations corporation in America” may only have been technically true in terms of its number of personnel and accounts, its reputation for fundraising helped it continue to expand. ${ }^{17}$

Most of the Corporation's efforts in these early years dealt with domestic matters, and fund raising for higher education continued to be its most significant area of business. However, the corporation's first significant campaign in support of international issues was its work for the Woodrow Wilson Foundation. Announced in June 1921 and led by Independent editor Hamilton Holt, the foundation furthered Wilson's ideals, and world peace through justice and international organization in particular. By supporting the ideals of Woodrow Wilson, the Corporation became a representative of the eastern establishment internationalist elite. While nothing stopped the Corporation from taking on clients for whom it had little natural sympathy, the Corporation's staff clearly reflected what historian Robert Divine called the homogeneity of interwar internationalists. Largely drawn from or educated in the northeast, the majority were white, anglophile, Anglo-Saxon Protestants. The Corporation clearly highlighted the education of its staff in its literature, and as of 1936, more than half had been educated at Ivy League institutions while many others had attended northeastern liberal arts colleges such as Amherst, Bowdoin, and Williams. By 1939, they worked closely with like-minded internationalists dedicated to stopping aggression overseas.

\footnotetext{
${ }^{17}$ John Price Jones Corporation Service Manual for Fund Raising Campaigns, [c. 1936], John Price Jones Corporation folder, box 15, American Committee for Non-Participation in Japanese Aggression Papers, Houghton Library, Harvard University (hereafter ACNPJA Papers); Cutlip et al., Effective Public Relations, 123-25; Cutlip, Fund Raising in the United
} States, 178. 
The first links between the Corporation and the internationalists came in response to Japanese aggression in China. ${ }^{18}$

The American Committee for Non-Participation in Japanese Aggression (ACNPJA) was formed in 1938 by a group of Americans who felt the United States was not doing enough to help China following the outbreak of conflict with Japan in 1937. Henry Stimson took the role of honorary chairman but the daily running of the Committee was left to Chairman Roger Greene and the committee’s main impetus, Executive Secretary Harry B. Price. Frustrated with the lack of economic sanctions against Japan, they felt that the United States needed to stop providing material to Japan because doing so supported Japanese aggression. Yet even with such a clear political objective, the ACNPJA sought professional assistance from the rapidly developing field of public relations to maximize its effectiveness. In January 1939 the ACNPJA obtained the assistance of the John Price Jones Corporation, initially for just two weeks to raise awareness of the committee. However, the ACNPJA asked the Corporation to go further and provide advice and suggestions for the Committee's future organization, publicity and fund raising. ${ }^{19}$

${ }^{18}$ Washington Post, 27 Jun. 1921, p. 6; Cutlip, Unseen Power, 238; Robert A. Divine, Second Chance: the Triumph of Internationalism in America during World War II (New York: Atheneum, 1967), 22-23; John Price Jones Corporation Service Manual for Fund Raising Campaigns, [c. 1936], John Price Jones Corporation folder, box 15, ACNPJA Papers. ${ }^{19}$ Progress and Program of the American Committee for Non-Participation in Japanese Aggression, 16 Feb. 1940, Reports on Progress 1938 folder, box 16, ACNPJA Papers; Harry Price to Henry L. Stimson, 16 Dec. 1938, microfilm frames 0974-0977, reel 96, Henry L. Stimson Papers, Library of Congress, Washington DC; Stimson to Price, 27 Dec. 1938, folder 699, box 21, Roger Greene Papers, Houghton Library, Harvard University; Friedman, The 
After two weeks of preliminary investigation, the Corporation produced its report on suggested steps for the ACNPJA. In terms of organization, the Corporation suggested creating local committees in order to create a nationwide response, rather than simply relying on the leadership of the National Committee. The Corporation also noted that the ACNPJA's leadership needed strengthening to include "at least one man or woman from each of the social, economic, racial, religious, political or geographic groups” to be asked for support. This strong call for thematic breadth of representation in addition to numerical depth was a consistent message from public relations professionals throughout this period, as it would help organizations prove their legitimacy to the public. Ultimately to its detriment, the ACNPJA chose largely to ignore this advice, rejecting a mass membership approach to organization, although some particularly active supporters felt strongly enough to create local and largely autonomous committees of their own. ${ }^{20}$

With regard to publicity, the Corporation's main advice was the rather obvious point that the ACNPJA “urgently” needed publicity counsel to publicize its activities, whether this was promoting addresses from speakers, endorsements from prominent individuals, committee expansion, or statements from Washington on the volume of popular support for the ACNPJA's program. Finally, with regard to its operating schedule, the Corporation advised that the ACNPJA devote two weeks to clarifying its program, leadership, budget, and

Road From Isolation, 1-4; D. Kenneth Rose to Price, 5 Jan. 1939, John Price Jones Corporation folder, box 15, ACNPJA Papers.

${ }^{20}$ Suggested Steps for the American Committee for Non-Participation in Japanese Aggression, 25 Jan. 1939, John Price Jones Corporation folder, box 15, ACNPJA Papers; Progress and Program of the American Committee for Non-Participation in Japanese Aggression, 16 Feb. 1940, Reports on Progress 1938 folder, box 16, ACNPJA Papers. 
finding a "solution of its financing problem." On the latter point, it recommended that the ACNPJA concentrate on finding a few prospective large donors; unsurprisingly, it also proposed that "the services of an organization competent to direct this fund-raising should be obtained.” The ACNPJA did not take the hint, and the relationship with the Corporation did not continue, largely because the Corporation wanted more money than the limited existing ACNPJA funds could provide. ${ }^{21}$

With limited help from public relations professionals, the ACNPJA worked through 1939 and 1940 to spread the message about Japanese aggression across America. Looking back from the autumn of 1942, Harry Price believed that the Committee helped to "crack the isolationist front” on the issue of supplying war materials to Japan. However, without a mass membership, the ACNPJA ultimately had a limited public impact. Congress never passed the full embargo legislation demanded by the Committee. This was in part because the war in Europe soon became far more significant for Americans than the war in Asia. Yet it was also in part because the ACNPJA failed to follow the basic lessons of public relations laid out by the John Price Jones Corporation. John Price Jones himself hinted at the limited impact of “proper advocacy” with regard to the war in Asia. Writing in 1939, Jones argued that the amount given by Americans for Chinese relief was "woefully small, probably because there was lack of adequate advocacy or sponsorship for the cause.”22

${ }^{21}$ Suggested Steps for the American Committee for Non-Participation in Japanese Aggression, 25 Jan. 1939, John Price Jones Corporation folder, box 15, ACNPJA Papers. ${ }^{22}$ Price to E. Snell Hall, 1 Sept. 1942, ACNPJA Ending folder, box 16, ACNPJA Papers; John Price Jones and David McLaren Church, At the Bar of Public Opinion: A Brief for Public Relations (New York: Inter-River Press, 1939), 69-70. 
By far the closest, longest and most effective relationship between a public relations company and a citizens’ committee at this time was between the John Price Jones Corporation and the Committee to Defend America by Aiding the Allies (CDAAA). The CDAAA had its immediate origins in a short lived organization created immediately following the outbreak of the European war. A desire to amend America's strict neutrality laws and aid victims of aggression quickly led to the creation of the Non-Partisan Committee for Peace through Revision of the Neutrality Act (NPC). Run by League of Nations Association and American Union for Concerted Peace Efforts director Clark Eichelberger and chaired by Emporia Gazette editor William Allen White, the NPC went public on 2 October 1939. Like the ACNPJA before it, the NPC recognized the need for public relations support and used the John Price Jones Corporation for public relations advice in promoting its campaign for neutrality revision. ${ }^{23}$

This advice was reflected in the methods used by the NPC organization and its methods during its brief existence. The NPC sought legitimacy by making itself as representative as possible and including leaders from all walks of life. It also utilized all possible media channels of promotion to rally public opinion behind the cause of neutrality revision. That public support was then reflected back through media coverage and public

${ }^{23}$ The American Union for Concerted Peace Efforts evolved out of the existing and similarly named Committee for Concerted Peace Efforts. The Committee for Concerted Peace Efforts was formed in December 1937 in the aftermath of Franklin Roosevelt’s quarantine speech, and contained many members of the League of Nations Association. Press Release, Supplementary Information to Statement Issued by William Allen White at Emporia, Kansas, 3 Oct. 1939, AUCPE Releases folder, box 45, Clark Eichelberger Papers, New York Public Library, New York (hereafter Eichelberger Papers). 
pressure to Washington to ensure prompt legislative action. In the end, that legislative action was surprisingly prompt. The NPC achieved a considerable amount of publicity in its first two weeks, by which time much of the Congressional battle had been won. While the NPC played its part, the main factor in securing neutrality revision was the outbreak of war in Europe. However, while the NPC quickly dissolved, the CDAAA built upon its experience the following spring as events in Europe rapidly deteriorated. ${ }^{24}$

The CDAAA formed in May 1940 as an immediate response to the German blitzkrieg on western Europe. Based in New York City, the CDAAA was again chaired by William Allen White and directed by Clark Eichelberger. By the year's end, the CDAAA became a well-known national citizens' organization with close links to the Roosevelt administration, and members and local chapters in every state of the union except North Dakota. It was the dominant internationalist organization in 1940 and 1941, because it focused on both an immediate political issue, and one that had significant popular support. The CDAAA's high profile was due in part to publicity created by its direct competition with the leading noninterventionist organization of the era, the America First Committee. A major part of its success was also due to its relationship with the John Price Jones Corporation. ${ }^{25}$

The John Price Jones Corporation greatly enhanced the CDAAA’s strategy because Jones now directed the public relations lessons he learnt in Washington promoting Liberty

\footnotetext{
${ }^{24}$ Minutes of the Meeting of the Board of Directors, 16 Oct. 1939, Minutes 1939-40 AUCPE folder, box 53, Eichelberger Papers; Robert Dallek, Franklin D. Roosevelt and American Foreign Policy, 1932-1945 (Oxford: Oxford University Press, 1995), 204-205.

${ }^{25}$ Breakdown of Chapter Organization, 28 Apr. 1941, folder 7, box 11, Committee to Defend America by Aiding the Allies Papers, Seeley G. Mudd Library, Princeton University (hereafter CDAAA Papers).
} 
Loans back at the government. The CDAAA hired the Corporation in May 1940 and retained its services until August 1941. Originally hired for both public relations assistance and fundraising from June through November 1940, the Corporation then had its role officially reduced to fundraising assistance, although the line between the two blurred. Across the whole fifteen month period, the Corporation provided detailed advice on fund raising, publicity, organizational planning, the CDAAA's strengths and weaknesses, and weekly situation reports. The Corporation strongly recommended adapting CDAAA strategy to target "weak spots” and finding existing organizations with similar objectives with whom to cooperate. However, their advice went beyond organizational strategy and into the realm of policy and ideas, helping the CDAAA to clarify and tailor its message for the American people. ${ }^{26}$

Beyond publicity and strategy, the CDAAA initially retained the Corporation to supply assistance in the areas of fundraising, administration and organization, and business management. The Corporation's fundraising ability was crucial: by its own estimates, the Corporation claimed that it would have cost the CDAAA at least $\$ 15,000$ to compile the lists available as part of the Corporation's services. More convincingly, the Corporation also estimated that over three quarters of the CDAAA's funds came from individuals on Corporation lists. But the Corporation also provided essential support in terms of administrative personnel. From 17 May to 30 November 1940, the Corporation assigned between nine and twelve of its staff to the CDAAA under the supervision of John Price Jones

\footnotetext{
${ }^{26}$ Brief for a Survey and Plan, 2 Oct. 1940, “Brief,” volume 1, CDAAA Files, John Price Jones Company Records, Baker Library Historical Collections, Harvard Business School (hereafter JPJC records); CDAAA Review of Finances, 20 Dec. 1940, volume 11, CDAAA Files, JPJC records.
} 
himself. Corporation Director and Vice President Robert Duncan co-directed the account at the beginning, but long time staff member Alex W. Burger assumed control by the end of August. The additional staff served in a number of key executive roles for the CDAAA including Business Manager, Publicity Director, Director of the New York Chapter and Director of the National Women's Division. Crucial tasks performed by the Corporation's staff included the development of the CDAAA's general plan of organization, establishment of its office organizational systems, preparation of publicity materials, and provision of nationwide lists of donors as well as controlling all fund raising activity. Working with the Corporation also allowed the CDAAA to meet its personnel needs without the need to interview candidates for positions. ${ }^{27}$

From late May onwards, the Corporation worked with the CDAAA to develop its national organizational structure, putting together a plan for the CDAAA's organization from the executive committee down to local and cooperating committees. The Corporation inspired the CDAAA's attempts to develop relationships with other like-minded organizations, as it insisted the CDAAA analyze the programs of existing organizations to see how their objectives matched those of the CDAAA. In addition, the Corporation strongly urged that particular sectors of society be targeted for representation, particularly agricultural, labor, and religious groups, in order to enhance the organization's legitimacy. ${ }^{28}$

${ }^{27}$ Committee to Defend America by Aiding the Allies Addenda to Review of Finances, 14 Jan. 1941, Review of Finances, CDAAA file, volume 11, JPJC records.

${ }^{28}$ Brief of Organization Plan for the Campaign of the CDAAA, June 1940, Brief of Plan, CDAAA file, volume 1, JPJC records; Alfred C. Gumbrecht to John Price Jones, 2 Oct. 1940, Brief, CDAAA file, Volume 1, JPJC records. 
The Corporation specifically suggested organizing a women’s auxiliary, a labor section and a "negro section," and the CDAAA acted on this advice by creating National Divisions to bolster representation in areas of perceived weakness. They specifically adopted a "qualitative approach... to develop support in these 'weak spot' areas in which opposition is most likely to take root.” Three sections of society targeted due to their divided opinion of the growing international crisis were youth (particularly students), women, and labor. By October 1940 the CDAAA had established four National Divisions: the Youth Division, the College Division, the Women’s Division, and the Labor Division. Of the four, the most developed was the College Division, which had sixty-eight chapters by June $1941 .^{29}$

The Corporation also urged the CDAAA to approach the African American community, albeit with extreme caution. Reluctant to be seen as overly liberal with respect to domestic racial politics or interfering in local politics, CDAAA leaders never considered a separate Division because it was unlikely to achieve mass support and could lead to the loss of political support elsewhere. However, with a genuine sense that African American representation was important, the John Price Jones Corporation emphasized that African Americans needed targeting as they were particularly vulnerable to fifth column activities. Corporation Vice-President Harold J. Seymour expressed concern that the nation's thirteen

${ }^{29}$ Suggestions for Future Action of the CDAAA, 20 Jun. 1940, Suggestions on Activities CDAAA file, volume 1, JPJC records; Policies, Aims and Accomplishments of the CDAAA, 9 Oct. 1940, folder 15, box 9, CDAAA Papers; Andrew Johnstone, “To Mobilize a Nation: Citizens’ Organizations and Intervention on the Eve of World War II” in Andrew Johnstone and Helen Laville (eds) The US Public and American Foreign Policy (London: Routledge, 2010), 28-30; Memorandum on Chapter Organization, 9 Oct. 1941, folder 18, box 5, CDAAA papers. 
million African Americans were "peculiarly vulnerable” to fifth column activities. This concern was based on a number of factors: African Americans had been heroes in France during World War I but received no recognition for it; they suffered from a lack of employment opportunities; they lacked support from labor unions; and there was a sense of bitterness among those who had moved north since World War I only to find segregation even more pronounced than in the south. As a result, the CDAAA leadership appealed to individual African American leaders, such as A. Philip Randolph and Ralph Bunche, to join them. ${ }^{30}$

In terms of policies, the Corporation recognised that the CDAAA was most effective when it had specific policies to support and mobilize opinion behind. To maximise public support, the Corporation constantly urged the CDAAA to adopt a more active program, and to stop relying on the Roosevelt administration for initiatives. Throughout the latter half of 1940, the Corporation pushed the CDAAA to develop its future plans by producing new policy statements on issues. The Corporation even suggested specific issues to promote such as the transfer of planes to Britain, or to oppose such as the Axis Tripartite Pact of September 1940. Of course, the CDAAA rejected a number of suggestions from the Corporation, especially on matters of policy. Notably, the CDAAA did not adopt the suggestion (made as early as June 1940) to promote an immediate declaration of war on Germany prior to the attack on Pearl Harbor. The CDAAA did not adopt the suggestion to promote Atlantic

\footnotetext{
${ }^{30}$ Harold J. Seymour to John Price Jones and Robert Duncan, 14 Jun. 1940, “'Fifth Column’ Activities”, volume 1, CDAAA Files, JPJC records; Inderjeet Parmar, ““... another important group that needs more cultivation': The Council on Foreign Relations and the Mobilization of Black Americans for Interventionism, 1939-1941,” Ethnic and Racial Studies, 27 (September 2004), 717.
} 
convoys until March 1941. The Committee refused to follow the suggestion to shorten its cumbersome name to the more elegant "Committee to Defend America," although it did tinker with its name in 1941. The more advanced nature of the suggestions emanating from the Corporation suggested that the public relations firm was in fact more belligerent than the CDAAA itself. While the bolder policy suggestions may have simplified the debate for the public and been preferable from a public relations and communications perspective, they nonetheless would have been harder to sell politically. ${ }^{31}$

The most notable CDAAA policy objective in the late summer of 1940 was to support the Roosevelt administration in its efforts to provide the British Navy with fifty recently reconditioned over age American destroyers. By mobilizing public opinion behind a transfer, countering the legal arguments against a transfer, and ensuring Republican presidential candidate Wendell Willkie would not speak against it, the CDAAA helped to convince the President to move ahead with the destroyer-bases exchange. Roosevelt subsequently asked Press Secretary Stephen Early to contact William Allen White to "thank him and the organization for all they have done.” It was arguably the CDAAA’s finest hour. The CDAAA's executive committee subsequently recorded their gratitude to the John Price Jones Corporation for helping them achieve their aim of aid to Britain. ${ }^{32}$

${ }^{31}$ Situation Report, 15 Jul. 1940, 7 Oct. 1940, 21 Oct. 1940, Situation Reports, CDAAA file, volume 1, JPJC records; Suggestions for Future Action of the CDAAA, 20 Jun. 1940, Suggestions on Activities CDAAA file, volume 1, JPJC records.

${ }^{32}$ Situation Report, 29 Jul. 1940, Situation Reports, CDAAA file, volume 1, JPJC records; Franklin D. Roosevelt, The Public Papers and Addresses of Franklin D. Roosevelt: 1940 (London: Macmillan, 1941), 391-407; Franklin Roosevelt to Stephen Early, 5 Sept. 1940, PPF 1196, Franklin D. Roosevelt Papers, Franklin D. Roosevelt Library, Hyde Park, NY 
Over the next two months, the Corporation continually pushed the CDAAA to provide a more explicit policy statement, as the CDAAA continued to propose all possible aid to Britain but with little specific policy detail. This was a significant concern for the public relations firm. A Corporation assessment of the CDAAA's strengths and weaknesses revealed additional challenges facing the CDAAA on the eve of the 1940 election. On the positive side, the CDAAA was clearly the leading organization supporting aid to those fighting fascist aggression; indeed, it was the only national organization with a network of local committees mobilizing support for a more active foreign policy. That established position brought with it a certain amount of prestige, and on a more practical level, volunteer personnel and financial support. The Committee also clearly benefitted from the nationwide respect for William Allen White and from the “crusading” leadership of Clark Eichelberger. ${ }^{33}$ However, the Corporation highlighted a number of weaknesses with the CDAAA. Regarding its central message, the CDAAA now lacked a clear “fighting objective.” Where it was once out ahead of general public opinion, the events of the previous six months had overtaken the committee and seen it fall behind, a criticism highlighted by the fact that both presidential candidates were in support of maximum aid to Britain. In fact, the concept of aid "short of war," so important at the Committee’s beginning, had become a liability that was increasingly difficult to define. The most logical course was the one most likely to ensure the nation’s "ultimate national safety," although it was impossible to tell whether that course could be pursued without recourse to war. The Corporation also acknowledged that the

(hereafter Roosevelt Papers); Resolution, 7 Nov. 1940, Correspondence I-K folder, box 1, CDAAA Papers.

${ }^{33}$ Harold M. Weeks to John Price Jones, 30 Oct. 1940, Weak and Strong Points, volume 1, CDAAA Files, JPJC records. 
CDAAA lacked an obvious successor to take over the leadership if White could not continue, especially as it relied far too heavily on White for its public statements. More broadly, the CDAAA lacked both a clear plan of action and a cohesive "brain trust" group to develop a future program. Subsequent months proved that all of these perceived weaknesses were very real, with only a limited amount of success in overcoming them. ${ }^{34}$

The lack of new initiatives and policy direction meant the CDAAA's financial situation become increasingly uncertain through October and November 1940 as donations dried up, and the Committee became increasingly concerned with its reduced income. At the end of November, the CDAAA leadership decided to restrict the Corporation's services to fundraising only. Despite the expense of retaining the Corporation's services, the CDAAA acknowledged after consultation with local groups that the only alternative to professional fundraising assistance was to attempt to rely on a small number of individuals who might in turn seek to control CDAAA policy. ${ }^{35}$

The decision was untimely as the CDAAA immediately encountered its most significant public relations crisis with the resignation of William Allen White. On 23 December, the national press quoted White as saying “the only reason in God's world I am in this organization is to keep this country out of war.” He added the CDAAA was not in favor of repealing either the Neutrality Act or the Johnson Act. It quickly became clear that because his beliefs clashed with most of the CDAAA membership, he could not carry on as chairman

\footnotetext{
${ }^{34}$ Ibid.

${ }^{35}$ Situation Report, 7 Oct. 1940, 21 Oct. 1940, 25 Nov. 1940, Situation Reports, CDAAA

file, volume 1, JPJC records; Committee to Defend America by Aiding the Allies Addenda to Review of Finances, 14 Jan. 1941, Review of Finances, CDAAA file, volume 11, JPJC records.
} 
of the CDAAA, and he resigned on 2 January 1941. Given the circumstances, the Corporation conceded that publicity progress at this point was "not in our hands.” The Corporation acknowledged that one result of the controversy over White's statement was that the CDAAA was very much in the public eye, suggesting that all publicity was good publicity; however, it also acknowledged that the rift in the Committee led to public confusion. Fortunately, the public's attitude toward the organization quickly became more sympathetic as the CDAAA offered its full support for the Roosevelt's Lend-Lease bill, which offered virtually unlimited aid to Britain. The Committee played a significant role in the popular debate over the bill, countering the strong opposition of the America First Committee. ${ }^{36}$

With the passage of the bill in March however, the public increasingly questioned the need for CDAAA. After all, as the Lend-Lease Act offered all possible aid to the allies, it appeared the Committee's work was complete. The Corporation was all too aware of this sentiment, and from the beginning of April it acknowledged that the public felt the CDAAA was "no longer needed" and did not understand why the organization might need further financial donations. The CDAAA’s finances urgently needed a boost. Despite having raised \$343,244.16 since 17 May 1940, the available balance as of 14 April 1941 was a paltry \$561.86. With an estimated \$150,000 required for the next six months of operations, weekly expenses were considerably higher than weekly income, and the CDAA considered drastic

\footnotetext{
${ }^{36}$ Johnson, Battle Against Isolation, 181-83; Situation Report, 30 Dec. 1940, 6 Jan. 1941, 1 Mar. 1941, Situation Reports, CDAAA file, volume 1, JPJC records.
} 
staffing reductions. Donations rose at the end of April but by June the Committee's financial situation was again in a state of crisis, and remained that way until December $1941 .{ }^{37}$

The Corporation's led the efforts to respond to the CDAAA's financial crisis by targeting specific sectors of society for funds. Throughout the spring the Corporation solicited money from supposedly new and untapped markets: women, southerners deemed to be particularly supportive of the internationalist cause, and the international business community of “exporters and importers.” By June, the Corporation adopted a more individual approach of "personal solicitation” to pursue specific wealthy donors for larger gifts, with selected "business men” approached in a similar vein in July. However, it had little lasting effect on the CDAAA's finances. The lack of a prominent national chairman and figurehead to replace William Allen White was also a significant handicap. ${ }^{38}$

Public support for the organization declined between the passage of Lend-Lease and July 1941. While aiding Britain was still a popular idea, suggesting American ships convoy that aid across the Atlantic was a far less acceptable idea. The decline in interest led to a further reduction in donations and subsequent alarm within the CDAAA about its falling

${ }^{37}$ Situation Report, 5 Apr. 1941, 21 Apr. 1941, Situation Reports, CDAAA file, volume 1, JPJC records; Mrs Harriman File, 15 Apr. 1941, OF 4230, Roosevelt Papers; Greene to Hugh Moore, 23 Jun. 1941, folder 20, box 5, Hugh Moore Fund Papers, Seeley G. Mudd Library, Princeton University; Situation Report, 28 Apr. 1941, 9 Jun. 1941, Situation Reports, CDAAA file, volume 1, JPJC records.

${ }^{38}$ White was replaced by former Vermont Senator Ernest W. Gibson Jr., but he too resigned in May 1941 when he was called up for active service in the US Army. Situation Report, 21 Apr. 1941, 23 Jun. 1941, 21 Jul. 1941, Situation Reports, CDAAA file, volume 1, JPJC records. 
income. The CDAAA's executive committee decided to terminate the Corporation's service as of 16 August. Despite the CDAAA’s need to raise funds, it could no longer justify employing such an expensive a fundraising Corporation. Although the relationship between the CDAAA and the Corporation ended with a whimper, the Corporation had clearly enhanced the CDAAA’s bank balance. The bottom line was that by 18 August 1941, the Corporation had helped the CDAAA raise $\$ 457,521.34$. By way of comparison, the America First Committee national headquarters received approximately \$370,000 during the longer period from July 1940 to February 1942. ${ }^{39}$

Still, the ongoing importance of good public relations counsel was reflected in the fact that CDAAA recognized that it still needed external support, and through the latter half of 1941 it looked for cheaper options. In October, it approached the New York based AllenMcIntosh Company, who urged the CDAAA to focus on a specific policy and to gain publicity through a large public forum event. Although a contract was signed at the end of October, the CDAAA's connection with Allen-McIntosh was fleeting and never as close as it had been with the John Price Corporation. In addition, in June the CDAAA developed its own in-house committee on public relations, led by Chester LaRoche, president of the advertising firm Young and Rubicam. However, the CDAAA clearly missed the all-round organizational, strategic and fund-raising expertise offered by the John Price Jones Corporation in the three months immediately preceding the Pearl Harbor attack. ${ }^{40}$

${ }^{39}$ Situation Report, 26 Jul. 1941, 11 Aug. 1941, 18 Aug. 1941, Situation Reports, CDAAA file, volume 1, JPJC records; Moore to Ellsworth Bunker, 6 Jul. 1941, Correspondence: Moore, Hugh 1941 Jun-1942 Feb folder, box 2, CDAAA Papers; Cole, America First, 32. ${ }^{40}$ McIntosh Memorandum, 22 Oct. 1941, Correspondence M (3 of 6) folder, box 1, CDAAA Papers; Contract Letter, 27 Oct. 1941 Correspondence : White, William Allen 1940 Jun-1941 
The John Price Jones Corporation greatly assisted the CDAAA through 1940 and 1941, from the provision of personnel to the organization's national headquarters, to the way the Corporation organized and structured the CDAAA and sought support from different sectors of society. It was clear from the fundraising efforts that kept the organization afloat, and also in the way the Corporation helped the internationalists refine their message and spread it to the American people. Public relations activity and support unquestionably enhanced the national profile of the CDAAA, a fact the internationalist leadership clearly recognized.

However, the Corporation could not solve all of the CDAAA's problems. The Corporation's insider critiques of the CDAAA - and indeed the wider internationalist movement - are in many ways more effective than that of the non-interventionist opposition such as America First. Paid to find weak spots in the internationalist movement's organization, the Corporation did exactly that, effectively highlighting its organizational limitations. Following White's resignation, the CDAAA never found a leader of comparable standing, let alone one to match the America First Committee’s Charles Lindbergh. The CDAAA also failed to consistently target and counter pockets of non-interventionist strength in the country, choosing the easier path of building on areas of existing strength. The Corporation highlighted the drawbacks to the limited rhetoric of the CDAAA, and its reliance on the Roosevelt Administration for a program of activity. The unwillingness of the CDAAA leadership to move in advance of Roosevelt's policies or to suggest specific ideas for fear of undermining the president ultimately left the organization with too few specific policies to support and too little to rest (what the Corporation called) "a case” upon. This unwillingness

Oct folder, box 2, CDAAA Papers.; Moore to Chester La Roche, 14 Jun. 1941, Fundraising Finance Committee Correspondence (I-M) folder, box 29, CDAAA Papers. 
led to a serious reduction in fund raising in 1941, and the rise of the more belligerent Fight For Freedom committee which advocated direct entry into the war.

Fight For Freedom (FFF), created in April 1941 following the passage of the LendLease Act, had a much more direct "fighting objective" in arguing that the existing war in Europe was already America’s to fight. With Senator Carter Glass as Honorary Chairman and Bishop of Southern Ohio Henry W. Hobson, the organization grew in prominence and attempted to replace the CDAAA as the main internationalist - indeed, outright interventionist - organization. Its director, Ulric Bell, had previously been Washington Correspondent for the Louisville Courier-Journal, and his efforts drove the organization forward through 1941. Like its predecessors, Fight For Freedom recognized the need for advice and assistance on getting its objectives out to the public. For public relations assistance, FFF looked to the New York firm of Tamblyn and Brown, building on a connection set up by Fight for Freedom's informal predecessor, the Century Group, back in the summer of 1940 .

Created in 1920 by two members of the fundraising firm Ward, Hill, Pierce and Wells, Tamblyn and Brown focused on a mix of fundraising and publicity much like the John Price Jones Corporation. However, the publicity created by Tamblyn and Brown existed almost wholly to facilitate the fundraising, not for broader strategic purposes. Nevertheless, with George Tamblyn focused on fundraising and John Crosby Brown in charge of publicity, the New York firm attempted to bring Fight For Freedom the level of national visibility held by the CDAAA and the America First Committee. However, they were largely unsuccessful, 
due in large part to the limited popularity of the organization's call for war, and the related fact that organization had restricted funds. ${ }^{41}$

Tamblyn and Brown's assessment of FFF's public relations effectiveness in June 1941 was extremely critical, much like the John Price Jones Corporation’s view of the CDAAA. It acknowledged that the organization had a publicity department and was effective in dealing with newspapers. However, its national organizing job was "badly done” and it had no effective fundraising at all. Tamblyn and Brown effectively acted as the committee's fundraising arm, with an office at FFF headquarters in Rockefeller Center. It organized regular promotional and fundraising events with diverse sectors of New York society: November's meetings included the Princeton club, a group of lawyers, and representatives of the paper industry. By December 10, Tamblyn and Brown had sourced contributions to the value of $\$ 68,401.60$, over one quarter of FFF's total contributions. ${ }^{42}$

Despite this success, FFF director Ulric Bell was unsatisfied and became increasingly frustrated with what he saw as a lack of fundraising from the very organization he was paying to raise funds. In August, clearly frustrated at FFF's limited resources, he denounced the “preponderous [sic] claims about money raised by Tamplyn [sic] and Brown, when in fact most of the contributions claimed to your activity are from sources you have nothing

\footnotetext{
${ }^{41}$ Cutlip, Fund Raising in the United States, 165-66. Tamblyn and Brown actually worked with the John Price Jones Corporation in 1941, raising funds for the newly created United Service Organizations. See Cutlip, Fund Raising in the United States, 401.

${ }^{42}$ Memorandum, 9 Jun. 1941, folder 3, box 51, Fight For Freedom Papers, Seeley G. Mudd Library, Princeton University (hereafter FFF Papers); Finances memo, undated, folder 10, box 53, FFF Papers; Situation Report, 1 Dec. 1941, folder 11, box 51, FFF Papers; Cash statement, 10. Dec. 1941, folder 1, box 52, FFF Papers.
} 
whatever to do with in soliciting.” Yet despite his frustrations, Bell kept the firm on right up to Pearl Harbor, clearly recognizing the need for greater resources and publicity. In the end, its overall impact was largely limited to fundraising, and Tamblyn and Brown unquestionably had an impact on the finances of Fight for Freedom. However, FFF lacked the clear organizational structure of the CDAAA (even though FFF's limited organizational structure and strategy drew heavily from the CDAAA's example). This organizational weakness combined with FFF's more provocative policy stance to limit its effectiveness through 1941.43

To varying degrees, public relations professionals provided advice, support, and structure to internationalist organizations fighting to break down American resistance to international engagement. When collaboration worked best, as with the CDAAA, public relations support sharpened internationalist messages, raised funds, organized and manned offices, and created the appearance of a broad base of national support for action in the face of international aggression. Other collaborations were less successful, dependent in part on the amount of public interest and support for a particular issue. Regardless of the level of success, all of the organizations knew public relations support was necessary to spread their message effectively in the fight against non-interventionism.

\section{Failing to Articulate Sentiment: the America First Committee}

The non-interventionist movement also recognized that public relations assistance was essential in spreading its message as widely and successfully as possible to the American people. The America First Committee, established in September 1940 to counter the CDAAA and mobilize public opinion for a greater emphasis on American national defense, recognized

\footnotetext{
${ }^{43}$ Ulric Bell to A. W. MacCarthy, 23 Aug. 1941, folder 4, box 51, FFF Papers.
} 
that it urgently needed public relations advice. Yet while the use of public relations assistance clearly helped the internationalist movement on the eve of war, the America First Committee failed to develop a close and effective relationship with public relations specialists. This was not for lack of trying, but America First failed to secure the assistance of its preferred public relations firm because that firm recognized that it would be bad public relations to formally associate with the "isolationist" organization.

In the wake of the Nazi blitzkrieg of May and June 1940, Yale student R. Douglas Stuart sought a way to ensure that the United States stayed out of the European conflict. As the summer progressed, Stuart contacted General Robert E. Wood, chairman of Sears Roebuck and Co., about developing a non-interventionist organization to rival the CDAAA. Formally announced in September the day after the destroyer-based exchange was confirmed, the America First Committee immediately engaged in the national foreign policy debate. With Wood as chairman and Stuart as national director, America First relied heavily on politicians for publicity, regularly utilizing Congressional figures such as Gerald Nye and Burton Wheeler. Its most prominent member was not a politician but Colonel Charles Lindbergh, whose personal history and fame made him the most popular member of the America First Committee, even though he only formally joined the national committee in April 1941. Nevertheless, America First rapidly grew in popularity, developing chapters across the country with particular strength in the Midwest and around Chicago. ${ }^{44}$

Despite the fact the America First Committee is more well-known than any internationalist organization of this era, and the fact that it claimed to have hundreds of thousands of members, it was in fact a relatively small scale operation in terms of its national executive office. America First leaders focused on organizing chapters to show volume of

\footnotetext{
${ }^{44}$ Cole, America First, 11-12; Doenecke, Storm on the Horizon, 165.
} 
grass-roots support rather than showing the quality of that support through connections to politicians or well-known Americans. Despite efforts to secure it, America First never had professional fund-raising support. While America First was reasonably effective at securing publicity through advertising and radio programming, it focused on getting its message out as frequently as possible with no overall public relations strategy. This (lack of) strategy reflected the fact that a number of key advisors to the America First executive committee were advertising men rather than public relations men, including Bruce Barton (of Batten, Barton, Durstine and Osborn), and William Benton and Chester Bowles (of Benton and Bowles). Nevertheless, Stuart later described Benton as a "master of public relations," as well as acknowledging the work of publicity director Sidney Hertzberg and vice-chairman Hanford MacNider. However, the America First leadership recognized self-help was not enough. ${ }^{45}$

The fact that America First knew it needed more effective public relations is evidenced by assistant director of organization Harry Schnibbe’s heavily annotated copy of Edward Bernays' Speak up for Democracy in the America First archives. Stuart acknowledged that they had to make it seem that public opinion was swinging their way: "we must use Roosevelt's old trick of making it appear as if public opinion is powerfully with us.”

${ }^{45}$ Robert Wood to Walter Shaw, 1 May 1941, Se folder, box 81, AFC Papers; Howard Beaver to R. Douglas Stuart, 29 Apr. 1941, B: Jan to April folder, box 58, AFC Papers; Robert D. Stuart, Jr. Making a Difference: Memoirs of a Lucky Man (Chicago: Coventry Group, 2006), 73-74. Also see Sidney Hyman, The Lives of William Benton (Chicago: University of Chicago Press, 1969), 238-239; Howard B. Schaffer, Chester Bowles: New Dealer in the Cold War (Cambridge: Harvard University Press, 1993), 26-32. Bowles was the only one of these three advertising men who officially joined the national committee. 
Yet for the committee's first six months, it had no external public relations support. The idea of contacting Bernays was raised but never explored, and initial attempts in late 1940 to work with the Chicago based firm of William Harshe Inc. fell through. In the spring of 1941, desperate for assistance in the aftermath of the passage of the Lend-Lease Act, the committee approached James Selvage of the New York firm Selvage and Smith. ${ }^{46}$

James Selvage had previously undertaken public relations work for the National Association of Manufacturers in the 1930s, attacking Roosevelt's New Deal for its excessive governmental intervention into business affairs. This anti-Roosevelt stance made Selvage a natural fit for the America First Committee in a similar way to how the internationalistminded John Price Jones Corporation was ideally suited to working with the CDAAA. National Committee member and former Undersecretary of State William Castle urged Stuart to secure Selvage as "we have got to have much better organization than we have at present, and it is pretty late to get it.” As the Lend-Lease debate came to a close, Selvage wrote a vivid and detailed memo on the need for America First to broaden its vision and "to pitch its efforts upon a more dramatic plane, reaching for the type of semi-hysteria that makes people want to join up and do battle.” He urged the committee to build up Herbert Hoover and Charles Lindbergh as patriotic leaders, to provide assistance to sympathetic Senators and Congressmen, to target women as the mothers and wives of those men who would be called to fight, and to look for the support of young men who would defend their own country "but

\footnotetext{
${ }^{46}$ Edward L. Bernays, Speak up for Democracy (New York: Viking Press, 1940), box 296, AFC Papers; Stuart to Wood, 26 Apr. 1941, Stuart R D Jr folder, box 57, AFC Papers; Robert Bliss memo, 9 Dec. 1940, Organization of Chapter folder, box 285, AFC Papers; William Harshe to Stuart, 14 Nov. 1940, Senate Foreign Relation folder, box 66, AFC Papers. Selvage and Smith would later become Manning, Selvage and Lee.
} 
are not anxious to go on a Holy Crusade to sell the New Deal ideology over the world as against the ideologies of Hitler, Stalin, and Mussolini." 47

Stuart approached Selvage in late March 1941, arguing to Robert Wood that "we need the skill, the experience, and the ability of Selvage's firm. This is not a two-bit operation ... without any question we need Selvage.” Stuart described securing Selvage’s services as “imperative.” Yet while Selvage was very sympathetic and offered informal advice to the America First executive committee, he refused to provide his services to America First formally. Selvage initially highlighted that the committee simply did not have the funds to pay the five or six thousand dollars per month required for a nationwide public relations program. Instead, Selvage provided America First with free advice when possible, most notably trying to convince the committee that "too much effort is being spent upon building chapters and membership when there isn’t time.” Instead, he argued it should focus its efforts on “propaganda and articulating sentiment swiftly, with organization secondary.” Much like the John Price Jones Corporation, Selvage emphasized the quality of the message and its recipients more than the quantity. ${ }^{48}$

America First was receptive to this message, along with other assistance on publicity, press releases, and how to respond to Secretary of the Interior Harold Ickes's suggestion that

\footnotetext{
${ }^{47}$ William Castle to Stuart, 17 Apr. 1941, Correspondence with Nat Com members folder, box 63, AFC Papers; Memorandum, undated, James Selvage folder, box 67, AFC Papers. ${ }^{48}$ Stuart to James Selvage, 29 Mar. 1941, James Selvage folder, box 67, AFC Papers; Stuart to Wood, 26 Apr. 1941, Stuart R D Jr folder, box 57, AFC Papers; Stuart to Samuel Pettengill, 26 Apr. 1941, Samuel Pettengill folder, box 62, AFC Papers; Selvage to Wood, 11 Apr. 1941, James Selvage folder, box 67, AFC Papers; Selvage to Smith Richardson, 6 May 1941, James Selvage folder, box 67, AFC Papers.
} 
Robert Wood and Charles Lindbergh were Nazi fellow travelers. However, America First ignored other more radical suggestions from Selvage. Chester Bowles criticized Selvage’s idea of attacking the seemingly biased and pro-war Gallup poll as unconvincing. The America First leadership also rejected Selvage’s provocative idea of inviting William Allen White - recently resigned as CDAAA chairman - and defeated 1940 Republican presidential candidate Wendell Willkie to join the committee. Selvage also drafted a set of ten principles for America First and sent them to the national committee for comments, but the largely unfavorable response criticized the proposals for being overlong, trying to cover too much ground, and for highlighting what the committee was against rather than what it promoted. As with the internationalists, the America First Committee often rejected bolder proposed policy messages from the public relations professionals due to reasons of political complexity. ${ }^{49}$

Nevertheless, Stuart still sought the full-time services of Selvage and Smith through April and early May. After more pleading requests to join as a salaried member of the committee, Selvage finally detailed the reasons why he was reluctant to formally come on board. Despite his deep sympathy for the non-interventionist cause, he was genuinely concerned that he would lose clients as a result of any such association with America First.

${ }^{49}$ Cole, America First, 108; Selvage to Stuart, 14 Apr. 1941, James Selvage folder, box 67, AFC Papers; Selvage to Stuart, 29 Apr. 1941, James Selvage folder, box 67, AFC Papers; Bowles to Stuart, 1 May 1941, Chester Bowles folder, box 59, AFC Papers; Selvage to Stuart, 14 Apr. 1941, James Selvage folder, box 67, AFC Papers; Minutes of the Board of Directors, 28 Mar. 1941, Corporate records folder, box 337, AFC Papers; Minutes of the Board of Directors, 10 Apr. 1941, Corporate records folder, box 337, AFC Papers. For numerous responses to Selvage’s draft principles, see Letters on New Principles folder, box 291, AFC Papers. 
He feared some clients would disagree with his non-interventionist views and leave his firm, and that his ability to represent other clients would be reduced if he took a role with America First that required fighting with media outlets for air time. In his own words, he "could hardly raise hell with Columbia [Broadcasting System] one week for not giving us time and go the next week, nice-like, and say, 'I have a nice manufacturer who wants to talk over your air about something you don't object to so violently'.” The full realization of Selvage's fears came following a conversation with Bill Benton, who despite his own considerable wealth was unwilling to risk formally joining America First for fear of a similar business backlash against non-interventionist views. As the public relations firm was Selvage's only source of income to provide for his family, he believed the risk was too great. ${ }^{50}$

Selvage did not explicitly say why he believed that joining America First would alienate clients and media from NBC to the New York Times to Time, Life and Fortune. Yet the America First Committee had an unfortunately toxic brand in 1941. The slurs of internationalists such as Ickes stuck in the popular imagination, and the committee, however unfairly, was portrayed as one filled with Nazi sympathizers. Comments such as those made by Charles Lindbergh in Des Moines in September 1941 certainly opened the committee up to charges of anti-Semitism. To repair the committee's image was a vast undertaking, and even though Selvage believed in the cause, to try and support it would have been an all or nothing proposition in 1941, especially as he conceded that the America First assignment would be immediate and all-encompassing, Working for America First would betray Selvage's existing clients in the short term and leave him with little security in the long term. ${ }^{51}$

\footnotetext{
${ }^{50}$ Selvage to Smith Richardson, 6 May 1941, James Selvage folder, box 67, AFC Papers.

${ }^{51}$ Ibid.; New York Times, 12 Sept. 1941, p. 2.
} 
Although Selvage continued to correspond with Stuart into July, the America First Committee struggled through the remainder of 1941 without clear public relations direction. Chester Bowles occasionally consulted with the organization, and while Bill Benton and Bruce Barton had similar reservations to Selvage, they did what they could on an informal basis. At a lower level, the Director of Organization role was filled by Robert Bliss, Richard Moore, then Page Hufty, who did what little they could with limited finances to build on the advice from Selvage, match the CDAAA, and expand the America First membership in a qualitative sense. Hufty in particular worked to incorporate women and African Americans into the committee, the latter through the Charles A. Young division in Washington. Sidney Hertzberg's exit as Director of Publicity in March 1941 was one of the reasons Stuart was so desperate to secure Selvage. Although Richard Moore replaced in Hertzberg in July, it was never quite enough. Attempts to develop a more formal publicity unit under the active but abrasive John T. Flynn, another staunch anti-New Dealer and head of America First's New York chapter, had only just begun to be discussed by the time of the attack on Pearl Harbor. ${ }^{52}$

America First's continued yet limited efforts to secure public relations assistance reflected how valuable they deemed that assistance to be. The knowledge that the organization was at a disadvantage compared to their opponents was partly responsible for those efforts: General Wood openly conceded that "we have never had a professional fund-

${ }^{52}$ Page Hufty to John Wheeler, 5 Aug. 1941, Page Hufty Correspondence folder, box 3, AFC Papers; Frederic Chase to Hufty, 14 Nov. 1941, Earl C Jeffrey folder, box 4, AFC Papers; Bruce Barton to Stuart, 13 Jan. 1941, Miscellaneous folder, box 56, AFC Papers; Robert Hutchins to Stuart, 18 Apr. 1941, Robert M. Hutchins folder, box 60, AFC Papers; John Flynn to Wood, 3 Dec. 1941, Abeyance folder, box 284, AFC Papers; Doenecke, ed., In Danger Undaunted, 56 n.52. 
raising organization such as the Committee to Defend America by Aiding the Allies” and that applied to public relations more broadly. But the search for support also reflected the organization's strong belief that public opinion could be - and indeed needed to be - molded and steered in a particular direction, away from war. In attempting to express complicated ideas to an increasingly "mass” public spread across a continent, the organization needed all the help it could get. ${ }^{53}$

\section{Legacy}

While the citizens' organizations on the eve of war were confident in their own message, they recognized that the urgency of the great debate required more than a series of press releases or advertisements for newspapers. The heightened sensitivity to public opinion - due to the international context, the democratic nature of the debate, and new polling methods and public relations techniques - meant that they sought new and effective ways to amplify their message to an increasingly interested and politically important public. The public relations assistance of the era helped in a number of key ways that went far beyond simply selling advertising, writing copy, and getting the internationalist or non-interventionist message out. They helped with administration and organization, notably with the John Price Jones Corporation's staffing of the CDAAA office; they helped the organizations address questions of public image; they brought force and clarity to arguments, though sometimes without full consideration of the political implications; they provided telling critiques of organizational weaknesses; and they urged the cultivation of widespread popular support, to secure political clout. However, more often than not, the message was to prioritize quality over quantity and breadth rather than depth in order to secure popular legitimacy. In that sense there was a

${ }^{53}$ Robert Wood to Walter Shaw, 1 May 1941, Se folder, box 81, AFC Papers. 
tension in the public relations message which sought the appearance of democracy without always being especially democratic.

Nonetheless, assisted by public relations professionals, the organizations certainly had national impact. The America First Committee crystalized the national reluctance for war, while the efforts of the CDAAA mobilized opinion to aid victims of aggression. The Roosevelt administration greatly appreciated the work of the internationalist organizations. Roosevelt had a preference for multiple agencies and decentralized control, but he was also wary of the memory of the Committee on Public Information and reluctant to create a national propaganda agency before the nation was at war. Yet through the CDAAA he received an informal propaganda service. As historian Michael Sherry has noted, Roosevelt rejected a more formal propaganda agency in peace time "in favor of an informal publicprivate cooperation that would largely prevail for decades after the war.” Public relations considerations were a key part of that ongoing cooperation. ${ }^{54}$

After the great debate, close links between public relations and foreign relations became commonplace. When the government finally did create a domestic wartime propaganda apparatus - first under the Office of Facts and Figures, then with the Office of War Information - it was all too aware of the heightened importance of domestic public opinion when it came to American foreign relations. The director of the wartime Office of Facts and Figures, Archibald MacLeish, sought to utilize "all the techniques of public opinion research which have been developed in the government, private foundations, business and industry in the past several years," which included the work of public relations professionals. MacLeish and others later took these techniques into the Department of State following its

\footnotetext{
${ }^{54}$ Michael S. Sherry, In the Shadow of War: the United States since the 1930s (New Haven: Yale University Press, 1995), 54.
} 
reorganization in 1944 and the creation of the Office of Public Information, later the Office of Public Affairs. Undersecretary of State Edward Stettinius even went so far as to send the Department’s John Sloan Dickey to meet with public relations pioneer Arthur Page, Vice President of Public Relations for AT\&T, to test if Dickey’s ideas about public relations were up to the highest standards of the private sector. By 1945 politicians accepted the need for public relations strategies, adopting them into both domestic public affairs management and in public diplomacy efforts overseas. ${ }^{55}$

The expansion of public relations ideas only continued in the Cold War and beyond. Even as the concept of public relations broadened out to be incorporated by numerous government departments, and the definitions of public relations and propaganda became increasingly blurred, the involvement of private public relations firms in matters of American foreign relations continued. This included the work of Harold Oram, whose firm - among other roles - did public relations work for Ngo Dinh Diem in the United States in the 1950s. In the same decade, the French hired an American public relations firm to try and influence attitudes on their war in Algeria. More recently, Hill and Knowlton sparked controversy over

${ }^{55}$ MacLeish cited in Hart, Empire of Ideas, 75; John Sloan Dickey interview by Jere Daniell, 3 Mar. 1975, tapes 1-11, transcript, p. 166-67, Rauner Special Collections Library, Dartmouth College, http://www.dartmouth.edu/ library/rauner/archives/oral_history/dickey/docs_interviews/JSD Tapes1-11.pdf; Andrew Johnstone, “Creating a 'Democratic Foreign Policy’: The State Department's Division of Public Liaison and Public Opinion, 1944-1953,” Diplomatic History, 35 (June 2011), 483-503. 
their work for Citizens for a Free Kuwait prior to the first Gulf War. For as long as wars of ideas continue, the need for successful public relations will follow. ${ }^{56}$

${ }^{56}$ Joseph G. Morgan. The Vietnam Lobby: The American Friends of Vietnam, 1955-1975 (Chapel Hill: University of North Carolina Press, 1997), 51; Matthew Connelly, A Diplomatic Revolution, Algeria's Fight for Independence and the Origins of the Post-Cold War Era (Oxford: Oxford University Press, 2002), 138; David Miller and William Dinan, A Century of Spin: How Public Relations Became the Cutting Edge of Corporate Power (London, Pluto Press, 2008), 100-101. For a broader definition of public relations in this period, see Kenneth Osgood, Total Cold War: Eisenhower's Secret Propaganda Battle at Home and Abroad (Lawrence: University Press of Kansas, 2006). 